\title{
ORIGINAL CLINICAL SCIENCECirculating miR-181a-5p as a new biomarker for acute cellular rejection in heart transplantation
}

\author{
Ignacio Constanso-Conde, ${ }^{\mathrm{a}}$ Manuel Hermida-Prieto, ${ }^{\mathrm{a}}$ Eduardo Barge-Caballero, ${ }^{\mathrm{b}}$ \\ Lucía Núñez, ${ }^{\text {a }}$ Jorge Pombo-Otero, ${ }^{\text {c }}$ Natalia Suárez-Fuentetaja, ${ }^{\text {ca }}$ María Jesús \\ Paniagua-Martín, ${ }^{\mathrm{b}}$ Gonzalo Barge-Caballero, ${ }^{\mathrm{b}}$ David Couto-Mallón, ${ }^{\mathrm{b}}$ Ricardo Pan- \\ Lizcano, ${ }^{\mathrm{a}}$ José Manuel Vázquez-Rodríguez, ${ }^{\mathrm{b}}$ and María Generosa Crespo-Leiro ${ }^{\mathrm{b}}$
}

a Grupo de investigación en Cardiología, Instituto de Investigación Biomédica de A Coruña (INIBIC), Complexo Hospitalario Universitario de A Coruña (CHUAC), SERGAS, Universidade da Coruña (UDC), Spain.

b Servicio de Cardiología, Instituto de Investigación Biomédica de A Coruña (INIBIC), Complexo Hospitalario Universitario de A Coruña (CHUAC), CIBERCV, SERGAS, Universidade da Coruña (UDC), Spain.

c Servicio de Anatomía Patológica, Complexo Hospitalario Universitario de A Coruña (CHUAC) SERGAS, A Coruña, Spain.

\begin{abstract}
:
Background: Acute cellular rejection (ACR) is a major complication in heart transplantation (HTx). Endomyocardial biopsy is the reference method for early detection of ACR, but a new non-invasive approach is needed. Tentative candidates could be circulating microRNAs. This study aimed to discover and validate microRNAs in serum for ACR detection after HTx.

Methods: This prospective, observational, single-center study included 121 HTx patients. ACR was graded according to International Society of Heart and Lung Transplantation classification $(0 R-3 R)$. First, in the discovery phase, microRNA expression profile was carried out in serum samples from patients at prerejection, during, and post-rejection time $\left(0 \mathrm{R}_{\mathrm{S} 1} \rightarrow 2 \mathrm{R}_{\mathrm{S} 2} \rightarrow 0 \mathrm{R}_{\mathrm{S} 3}\right)$. Relative expression $\left(2^{-\Delta \mathrm{Cq}}\right)$ of 179 microRNAs per sample was analyzed by reverse transcription quantitative polymerase chain reaction. Second, a microRNA with a significant rise and fall pattern during ACR was selected for the next validation phase, where it was analyzed (reverse transcription quantitative polymerase chain reaction) in serum samples from 2 groups of patients: the no-ACR group (0R grade) and the ACR group ( $\geq 2 \mathrm{R}$ grade). Finally, a sensitivity analysis (receiver operating characteristic curve) was done to assess microRNA accuracy for ACR detection in HTx.

Results: A total of 21 ACR episodes $\left(0 \mathrm{R}_{\mathrm{S} 1} \rightarrow 2 \mathrm{R}_{\mathrm{S} 2} \rightarrow 0 \mathrm{R}_{\mathrm{S} 3}\right)$ with their respective serum samples (n=63) were included in the discovery phase. Among the 179 microRNAs analyzed, only miR-181a-5p met the rise and fall criteria. In the validation phase, miR-181a-5p relative expression $\left(2^{-\Delta C q}\right)$ in the ACR group $(n=45)$ was significantly overexpressed $(\mathrm{p}<0.0001)$ vs the no-ACR group $(\mathrm{n}=45)$. miR-181a-5p showed an area under the curve of 0.804 (95\% confidence interval: $0.707-0.880$ ); sensitivity and specificity of $78 \%$ and $76 \%$, respectively; and a negative predicted value of $98 \%$.
\end{abstract}


Conclusions: miR-185a-5p in serum is a candidate as a non-invasive ACR biomarker (area under the curve = 0.80 and negative predicted value $=98 \%$ ). Thus, this biomarker could reduce the need for endomyocardial biopsies and the associated risks and costs of this invasive procedure.

Keywords:

Heart transplantation; Acute rejection; MicroRNA; miR-181a-5p; Biomarker

Heart transplantation (HTx) is the preferred option for patients with end-stage heart failure who are eligible. However, patients are at risk for developing several complications during the posttransplant period. ${ }^{1}$ One of the most frequent complications is acute cellular rejection (ACR), ${ }^{1}$ an alloimmune response where T-cell activation plays a central role. In fact, up to $25 \%$ of patients will present any grade of ACR during the first year after transplantation, and a significant minority of these patients will require treatment. ${ }^{1}$ The gold standard method to detect ACR has been the endomyocardial biopsy (EMB), which is an invasive and uncomfortable procedure for the patients with the potential risk of serious complications. ${ }^{2}$ Moreover, the possibility of sampling error with false negative results, as well as a pathological grading system with substantial observer dependency, ${ }^{3}$ make EMB a technique with important limitations.

Non-invasive methods ${ }^{4}$ (e.g., echocardiography, cardiac magnetic resonance imaging, and nuclear imaging) and the newest molecular techniques (e.g., gene expression ${ }^{5,6}$ and donor-derived cell-free $\mathrm{DNA}^{7}$ ) are being investigated to improve the diagnostic of ACR. In the last years, microRNAs have emerged as a potential biomarker. 8,9

MicroRNAs are small 21-25 single-stranded RNAs that regulate gene expression by binding to a complementary nucleotide sequence in messenger RNA. ${ }^{10}$ MicroRNAs possess many natural characteristics that make them excellent potential clinical biomarkers, as they are present in circulation and they are remarkably stable. ${ }^{8}$ Unique microRNA fingerprints that identify disease states ranging from cardiovascular disease to diabetes and cancer have been identified. ${ }^{911}$ In the field of HTx, at least 7 studies were performed trying to elucidate the possible role of microRNAs as ACR biomarkers (Table 1). ${ }^{12-18}$ Five studies analyzed the presence of circulating microRNAs, ${ }^{12,13,15-17}$ whereas the other 2 focus on the expression of microRNAs in EMB. ${ }^{14,18}$ However, the low replicability observed between these studies, with 12 different microRNAs reported as potential ACR biomarkers (Table 1), has been the main reason why many promising microRNA biomarkers have never reached the clinical setting. ${ }^{19}$ A possible explanation for the poor reproducibility in these studies could be the microRNA biological variation, the different microRNA profiles studied, and a deficient analytic standardization. ${ }^{20}$ Thus, in recent years, numerous recommendations have been emerging to standardize the entire microRNA analytic process. ${ }^{20}$ Moreover, the biological variation could be minimized with an appropriate study design. $^{21}$ These last considerations were carefully taken into account in this study that aimed to evaluate the potential of circulating microRNAs as biomarkers of ACR detection in HTx. 


\title{
Methods
}

\author{
Study design
}

This prospective, observational, single-center study included patients who underwent $\mathrm{HTx}$ between April 2013 and August 2018 in the Complexo Hospitalario Universitario A Coruña (A Coruña, Spain). The EMB protocol to monitor rejection was every 10 to 15 days in the first 2 months, every 20 days in Months 3 and 4, and monthly in Months 5 and 6. After the sixth month, in stable patients and without any episode of treated rejection, the next EMB was at 12 months; in those patients who had an episode of rejection treated or needed to reduce immunosuppression because of complications, EMBs were performed every 2 months up to 12 months. On the same day, before the EMB procedure, blood samples were drawn to monitor laboratory parameters according to the standard clinical practice of the HTx program, and the remaining serum volume was aliquoted and sent to the research laboratory. EMBs were graded according to the International Society of Heart and Lung Transplantation 2005 criteria for ACR: no rejection, 0R; mild rejection, $1 \mathrm{R}$; moderate rejection, $2 \mathrm{R}$; and severe rejection, $3 \mathrm{R} .{ }^{22}$ In this study, rejection was considered when EMB grade was $\geq 2 R$ (because in asymptomatic patients without graft dysfunction, it is usually the threshold for rejection treatment) and no rejection when EMB grade was 0R. The study was approved by the local Ethics Committee (Comite ético de investigación de Galicia, reference: 2015/311). The standard immunosuppression protocol was triple therapy with tacrolimus, mycophenolate mofetil, and prednisone. Patients received induction therapy mostly with basiliximab and, in certain cases such as sensitized patients, thymoglobulin. Treatment of rejection episodes was with intravenous steroid bolus, $250 \mathrm{mg}$ to 1,000 mg depending on severity, for 3 days. Written informed consent was obtained from all patients in accordance with the Declaration of Helsinki.

The study was performed in 2 phases. First, in the discovery phase, a microRNA expression profile was carried out to identify and select circulating microRNAs differentially expressed during ACR. Then, a microRNA with a significant rise and fall pattern during ACR was included in the later validation phase to assess their diagnostic value to detect ACR in HTx patients.

\section{Discovery phase}

In the discovery phase, the patients included were those in whom a Grade $\geq 2 \mathrm{R}$ EMB and a previous and a subsequent Grade 0R EMB (not necessarily the one that preceded or followed the Grade $\geq 2 \mathrm{R} E M B$, but the nearest ones) were reported. Serum samples matched in time with those EMBs were selected and called $0 \mathrm{R}_{\mathrm{S} 1}$ (pre-rejection), $2 \mathrm{R}_{\mathrm{S} 2}$ (rejection), and $0 \mathrm{R}_{\mathrm{S} 3}$ (post-rejection). The entire episode, named as $0 \mathrm{R}_{\mathrm{S} 1} \rightarrow 2 \mathrm{R}_{\mathrm{S} 2} \rightarrow 0 \mathrm{RS} 3$, and their 3 serum samples were always processed in the same run to minimize analytic variability.

RNA was isolated from $200 \mu \mathrm{l}$ of serum using miRNeasy Serum/Plasma Advanced Kit (Qiagen, Hilden, Germany). Total RNA was eluted in $21 \mu \mathrm{l}$ of RNase-free water, and complementary DNA synthesis was performed following miRCURY LNA RT Kit (Qiagen) instructions. A total of 179 microRNAs per serum sample (Supplementary Table S1, available online at www.jhltonline.org) were analyzed with the quantitative polymerase chain reaction (qPCR) kit miRCURY LNA miRNA Serum/Plasma Focus PCR Panel Kit (Qiagen) in a LightCycler 480 Real-Time PCR System (Roche, Basel, Switzerland). Roche LC software was used for acquiring the quantification cycle $(\mathrm{Cq})$ by the second derivative method. Detailed steps to perform RNA isolation, reverse transcription (RT), and qPCR are described in the Supplementary Material (available online). 
Table 1 MicroRNA Studies Associated with Cellular Rejection in Serum and/or Blood from Heart Transplantation Patients

Discovery phase

Validation phase

\begin{tabular}{|c|c|c|c|c|c|c|c|c|c|}
\hline Article & Sample type & Case vs control & $\mathrm{N}^{\circ}$ of miRNAs & $\begin{array}{l}\text { Normalized } \\
\text { method }\end{array}$ & $\begin{array}{l}\text { miRNAs } \\
\text { differentially } \\
\text { expressed } \\
(\mathrm{p}<0.05) \\
\end{array}$ & Case vs control & $\begin{array}{l}\text { Normalized } \\
\text { method }\end{array}$ & $\begin{array}{l}\text { miRNAs differentially } \\
\text { expressed } \\
(\mathrm{p}<0.05)\end{array}$ & AUC \\
\hline Present study & Serum & 21 (BACR, DACR, AACR) & 179 & Global Mean & miR-181a-5p & 45 ACR vs 45 & $\begin{array}{l}\text { Reference Gene } \\
\text { (miR-23b-3p + } \\
\text { miR-30c-5p } \\
\text { Geometric } \\
\text { mean) }\end{array}$ & miR-181a-5p & 0.80 \\
\hline \multirow[t]{2}{*}{$\begin{array}{l}\text { Sukma Dewi } \\
\text { et al }{ }^{12,17}\end{array}$} & Serum & $\begin{array}{l}10 \text { (BACR, DACR, } \\
\text { AACR) }\end{array}$ & 175 & Global Mean & $\begin{array}{l}\text { miR-27a-3p } \\
\text { miR-101-3p } \\
\text { miR-142-3p } \\
\text { miR-144-3p } \\
\text { miR-326 } \\
\text { miR-339-3p } \\
\text { miR-424-5p }\end{array}$ & ? & $\begin{array}{l}\text { Reference Gene } \\
\text { (miR-451) }\end{array}$ & $\begin{array}{c}\text { miR-142-3p } \\
\text { miR-326 }\end{array}$ & $\begin{array}{r}0.80 \\
0.86\end{array}$ \\
\hline & Serum & \multicolumn{4}{|c|}{ In this study, the previous discovery phase was used (Sukma Dewi et al., 2013) } & $26 \mathrm{ACR}$ vs $37 \mathrm{NR}$ & $\begin{array}{l}\text { Spike-in } \\
\text { (UniSp6) }\end{array}$ & $\begin{array}{l}\text { miR-27a-3p } \\
\text { miR-101-3p miR-142-3p } \\
\text { miR-144-3p miR-326 } \\
\text { miR-339-3p miR-424-5p }\end{array}$ & $\begin{array}{l}0.72 \\
0.75 \\
0.78 \\
0.70 \\
0.69 \\
0.71 \\
0.73\end{array}$ \\
\hline $\begin{array}{l}\text { Sukma Dewi et } \\
\mathrm{al}^{16}\end{array}$ & $\begin{array}{l}\text { Exosomal } \\
\text { from serum }\end{array}$ & 5 ACR vs 5 NR & 175 & $\begin{array}{l}\text { Reference Gene } \\
\quad(\mathrm{miR}-451\end{array}$ & $\begin{array}{l}\text { miR-92a-3p } \\
\text { miR-142-3p } \\
\text { miR-339-3p }\end{array}$ & & Not performed & & \\
\hline Guo et al ${ }^{15}$ & Blood & \multicolumn{4}{|c|}{ No discovery phase was performed, miR-29 was chosen according bibliography } & $\begin{array}{l}51 \text { (R2/R3) vs } 231 \\
\mathrm{RD}\end{array}$ & $\begin{array}{l}\text { Reference Gene } \\
\text { (RNU6) }\end{array}$ & miR-29 & 0.79 \\
\hline
\end{tabular}

AACR, after acute cellular rejection; ACR, acute cellular rejection; AMR, antibody-mediated rejection; AUC, area under the curve; BACR, before acute cellular rejection; DACR, during acute cellular rejection; NR, no rejection. 
A cut-off for unspecific amplification was set at $\mathrm{Cq}=37$. In the case of undetectable icroRNA, Cq was set to 37. Those micro-RNAs that were not detected in more than $80 \%$ of samples were excluded for further analysis to reduce statistical noise. The global mean method was used to normalize qPCR results expressed as relative expression $\left(2^{-\Delta C q}\right)$. The fold change $\left(2^{-\Delta \Delta C q}\right)$ method was used to compare the relative expression between samples.

MicroRNAs were selected for the next validation phase if they fitted the following 3 conditions:

1. Significant difference in microRNA relative expression $\left(2^{-\Delta C q}\right)$ between $0 R_{S 1}$ and $2 R_{S 2}$;

2. Significant difference in $\left(2^{-\Delta C q}\right)$ between $2 \mathrm{R}_{\mathrm{S} 2}$ and $0 \mathrm{R}_{\mathrm{S} 3}$; and

3. A rise and fall pattern in $\left(2^{-\Delta \mathrm{Cq}}\right)$.

\section{Validation phase}

Serum samples matched in time with Grade $\geq 2 \mathrm{R}$ biopsies and not used in the discovery phase were selected to form the ACR group. The same number of serum samples matched in time with OR grade biopsies and not used in the discovery phase were randomly selected to form the noACR group. All selected samples were processed in duplicate. RNA isolation, RT reaction, qPCR reaction, and data analysis were carried out as in the discovery phase. In this phase, the qPCR reactions were performed using individual primers and the miRCURY LNA miRNA PCR Assay Kit (cat: 339306, Qiagen). Cq geometric mean from previously selected reference genes, miR-23b3p, and miR-30c-5p was used to normalize results as in the global mean method (more details in Supplementary Material online).

\section{Statistical analysis}

Statistical analysis was performed using GraphPad Prism 8.0 software. Continuous variables are presented as mean $(95 \% \mathrm{CI})$ when normally distributed and as median (interquartile range, $<25$ $-75>$ ) when non-normally distributed. Categorical data are displayed as count and percentage (n, $\%)$. The normality distribution was tested by D'Agostino-Pearson and the Shapiro-Wilk test. Analysis of differences among 3 groups (discovery phase) was performed using one-way analysis of variance with matched data and post-hoc Tukey test (normally distributed) or Friedman's test with Dunn's correction (non-normally distributed). Unpaired Student's t-test (normally distributed) or Mann-Whitney U-test (non-normally distributed) was performed to compare the differences between 2 groups (validation phase). Relative microRNA expression levels $\left(2^{-\triangle \mathrm{Cq}}\right)$ were log-transformed (base2) before they were analyzed statistically. Pearson's correlation was used to measure the strength of a linear association between 2 variables and was denoted by r. A receiver operating characteristic (ROC) curve was generated for selected microRNAs with MedCalc software. Areas under the curve (AUCs) and their respective 95\% CIs were calculated to evaluate the sensitivity and specificity for detecting ACR. Negative predicted value (NPV) and positive predicted value (PPV) were calculated for the cut-off with maximum AUC (Youden index) and the prevalence for ACR obtained (\% EMB $\geq 2 \mathrm{R}$ ). A two-sided p-value $<0.05$ was considered statistically significant for all calculations. 


\section{Results}

\section{Study population}

A total of 121 patients were included in the study and their primary heart diseases were dilated cardiomyopathy ( $\mathrm{n}=45 ; 37 \%)$, ischemic cardiomyopathy ( $\mathrm{n}=44 ; 36 \%$ ), hypertrophic cardiomyopathy $(\mathrm{n}=13 ; 11 \%)$, congenital cardiomyopathy $(\mathrm{n}=6 ; 5 \%)$, valvular cardiomyopathy $(\mathrm{n}=5 ; 4 \%)$, and others $(\mathrm{n}=8 ; 7 \%)$. The median age of the recipients was 59 (interquartile range [IQR]: 49-65) years and 82\% of them were males. After excluding 4 patients (perioperative death), a total of 1,113 EMBs were performed in the remaining 117 patients, with a median number of EMBs per patient of 9 (IQR: 8-11). The number of EMBs according to ACR International Society of Heart and Lung Transplantation 2005 classification grading criteria was 0R = 565 (51\%), $1 \mathrm{R}=461$ (41\%), 2R = 75 (7\%), 3R = 2 (0.2\%), and not valid = $10(0.9 \%)$. Biopsies where antibody-mediated rejection (AMR) were detected, either isolated AMR ( $\mathrm{n}=3$, $0.3 \%)$ or concomitant with ACR $(n=17,1.5 \%)$, were excluded from the study.

Table 2 Patient Characteristics at Sampling in 0R, 2R, and 0R During the Discovery Phase

\begin{tabular}{|c|c|c|c|c|}
\hline $\mathrm{N}=21\left(0 \mathrm{R}_{\mathrm{s} 1} \rightarrow 2 \mathrm{R}_{\mathrm{s} 2} \rightarrow 0 \mathrm{R}_{\mathrm{s} 3}\right)$ & $0 \mathrm{R}_{\mathrm{S} 1}$ & $2 \mathrm{R}_{\mathrm{S} 2}$ & $0 \mathrm{R}_{\mathrm{S} 3}$ & p-value \\
\hline $\begin{array}{l}\text { Tacrolimus levels, ng/mL } \\
\text { (95\% CI) }\end{array}$ & $11.2(9.8-12.7)$ & $9.4(8.1-10.7)$ & $9.3(8.2-10.4)$ & allNS. \\
\hline $\begin{array}{l}\text { Serum creatinine, } \mu \mathrm{mol} / \mathrm{L} \\
\text { (IQR) }\end{array}$ & $149(130-170)$ & $133(120-146)$ & $144(124-164)$ & all NS. \\
\hline $\begin{array}{l}\text { Red blood cells, } \times 10^{12} / \mathrm{L} \\
(\mathrm{IQR})\end{array}$ & $3.46(3.27-3.66)$ & $3.57(3.30-3.84)$ & $3.81(3.59-4.03)$ & $0 \mathrm{R}_{\mathrm{S} 1} \mathrm{vs} 0 \mathrm{R}_{\mathrm{S} 3}<0.005$ \\
\hline $\begin{array}{l}\text { Blood platelets, } \times 109 / \mathrm{L} \\
\text { (IQR) }\end{array}$ & $176(146-206)$ & $166(138-193)$ & $173(143-203)$ & all NS. \\
\hline $\begin{array}{l}\text { White blood cells, } \times 10^{9} / \mathrm{L} \\
\text { (IQR) }\end{array}$ & $7.35(6.06-8.64)$ & $6.19(5.02-7.37)$ & $7.05(5.91-8.20)$ & all NS. \\
\hline $\begin{array}{l}\text { Blood lymphocytes, } \times 10^{9} / \mathrm{L} \\
(95 \% \mathrm{CI})\end{array}$ & $0.82(0.60-1.05)$ & $1.06(0.84-1.29)$ & $1.18(0.98-1.37)$ & $\begin{array}{l}0 \mathrm{R}_{\mathrm{S} 1} \text { vs } 2 \mathrm{R}_{\mathrm{S} 2}<0.050 \mathrm{R}_{\mathrm{S} 1} \\
\text { vs } 0 \mathrm{R}_{\mathrm{S} 3}<0.05\end{array}$ \\
\hline $\begin{array}{l}\text { Blood neutrophils, × 109/L } \\
\text { (IQR) }\end{array}$ & $5.99(4.71-7.27)$ & $4.48(3.50-5.46)$ & $5.17(4.13-6.20)$ & all NS. \\
\hline CMV viral load & & Undetectable & & - \\
\hline
\end{tabular}

CI, confidence interval; CMV, cytomegalovirus; IQR, interquartile range; NS, not significant

\section{Discovery phase}

Eleven patients with a $0 \mathrm{RS} 1 \rightarrow 2 \mathrm{R}_{\mathrm{S} 2} \rightarrow 0 \mathrm{R}_{\mathrm{S} 3}$ episode and 5 patients with $20 \mathrm{R}_{\mathrm{S} 1} \rightarrow 2 \mathrm{R}_{\mathrm{S} 2} \rightarrow 0 \mathrm{R}_{\mathrm{S} 3}$ episodes were included. Thus, $210 \mathrm{R}_{\mathrm{S} 1} \rightarrow 2 \mathrm{R}_{\mathrm{S} 2} \rightarrow 0 \mathrm{R}_{\mathrm{S} 3}$ episodes and their respective serum samples $(n=63)$ were selected. Patient characteristics at sampling in $0 R_{S 1}, 2 R_{S 2}$, and $0 R_{S 3}$ are detailed in Table 2. The time (days) elapsed from HTx to serum sample collection was 58 (IQR: 35-80) days for $0 \mathrm{R}_{\mathrm{S} 1}, 102$ (IQR: 79-125) days for $2 \mathrm{R}_{\mathrm{S} 2}$, and 178 (IQR: 139-216) days for 0RS3. It is important to note that the $0 \mathrm{R}_{\mathrm{S} 3}$ corresponds to the first $0 \mathrm{R}$ biopsy after the $2 \mathrm{R}$ rejection. However, it does not have to be necessarily the following biopsy after the $2 \mathrm{R}_{\mathrm{S} 2}$ because, in most of the patients, before the $0 R_{S 3}$ biopsy, there were several $2 R$ or $1 R$ biopsies. The immunosuppression regimen was tacrolimus, mycophenolate mofetil, and prednisone in $93.8 \%$ of patients and cyclosporine, mycophenolate mofetil, and prednisone in $6.2 \%$. Induction therapy with basiliximab was used in $93.8 \%$ of patients and with thymoglobulin in $6.2 \%$. Rejection episodes were treated with a 3-day intravenous bolus of methylprednisolone, $250 \mathrm{mg} /$ day (52.4\%), $500 \mathrm{mg} / \mathrm{day}$ (38.1\%), or $1 \mathrm{~g} /$ day (9.5\%). The 3 groups were comparable regarding tacrolimus levels, serum creatine, blood platelets, white blood cells, and blood neutrophils. A slight difference, although significant, was detected for red blood cell count between samples $0 \mathrm{R}_{\mathrm{S} 1}$ and $0 \mathrm{R}_{\mathrm{S} 3}$ and for blood lymphocyte count between sample $0 \mathrm{R}_{\mathrm{S} 1}$ and the other 2 samples. No patient had cytomegalovirus infection at the time of sampling (undetectable viral load). 
The mean Cq of the 63 serum samples was 34.71 (95\% confidence interval [CI]: 34.47-34.95) with no significant differences among the 3 groups ( $\mathrm{Cq}_{\text {oRs } 1}=34.65$ [95\% CI: 34.20-35.10], $\mathrm{Cq}_{2 \mathrm{Rs} 2}$ $=34.69$ [95\% CI: 34.26-35.13], and $\mathrm{Cq}_{\mathrm{oRs} 3}=34.80$ [95\% CI: 34.36-35.24]). Of the 179 microRNAs analyzed, 31 were not expressed $(\mathrm{Cq} \geq 37)$ in more than $80 \%$ of the samples, so they were eliminated for further analysis (Supplementary Table S1 online). Of the remaining 148 microRNAs, only 10 of them were expressed in $100 \%$ of the samples: miR-16-5p, miR-23a-3p, miR-25-3p, miR-30d-5p, miR-92a-3p, miR-150-5p, miR-223-3p, miR-320a, miR-320b, and miR486-5p. After data normalization, Supplementary Figure S1a online shows the 10 microRNAs with the highest relative expression $\left(2^{-\Delta \mathrm{Cq}}\right)$. MicroRNA fold change $\left(2^{-\Delta \Delta \mathrm{Cq}}\right)$ of the rejection group $\left(2 \mathrm{R}_{\mathrm{S} 2}\right)$ compared with the no rejection group $\left(0 \mathrm{R}_{\mathrm{S} 1}\right)$ showed 79 (53\%) micro-RNAs underexpressed and 69 (47\%) microRNAs overexpressed, with fold change $\left(2^{-\Delta \Delta \mathrm{Cq}}\right)$ values between -1.67 and 1.43 (Supplementary Figure S1b online).

Among the 148 microRNAs analyzed, 4 of them showed a significant difference in relative expression $\left(2^{-\Delta \mathrm{Cq}}\right.$ ) between the $0 \mathrm{R}_{\mathrm{S} 1}$ and $2 \mathrm{R}_{\mathrm{S} 2}$ groups: miR-181a-5p, miR-339-3p, let-7f-5p, and miR-505-3p (Figure 1). However, only miR-181a-5p showed a significant difference in $2^{-\Delta \mathrm{Cq}}$ between $2 \mathrm{R}_{\mathrm{S} 2}$ and $0 \mathrm{R}_{\mathrm{S} 3}$ and a rise and fall pattern.

To investigate whether the serum levels of miR-181a-5p could reflect blood lymphocyte count, a correlation was performed between both variables. There was no statistical correlation between miR-181a-5p and blood lymphocyte count. The Spearman's $r=0.170$ (95\% CI: -0.096 to 0.412 ) demonstrated that miR-181a-5p expression is independent of blood lymphocyte count. Therefore, miR-181a-5p was chosen to be evaluated in the next validation phase.

\section{Validation phase}

For the ACR group, 45 serum samples were found, $44 \mathrm{EMB}=2 \mathrm{R}$ and $1 \mathrm{EMB}=3 \mathrm{R}$. Therefore, the no-ACR group was completed with 45 random serum samples from patients with EMB $=0 \mathrm{R}$. The time (days) elapsed from HTx to serum sample collection was 51 (IQR: 26-99) days for the ACR group and 100 (IQR: 44-170) days for the no-ACR group. Patients' characteristics are detailed in Table 3. The immunosuppression regimen was tacrolimus, mycophenolate mofetil, and prednisone in 93\% of patients; cyclosporine, azathioprine, and prednisone in 4.7\%; and cyclosporine, mycophenolate mofetil, and prednisone in $2.3 \%$. Induction therapy with basiliximab was used in $93.5 \%$ of patients and with thymoglobulin in $6.5 \%$. Rejection episodes were treated with a 3-day intravenous bolus of methylprednisolone: $250 \mathrm{mg} /$ day (51.5\%), $500 \mathrm{mg} /$ day (36.4\%), or $1 \mathrm{~g}$ /day (6.1\%).There were no significant differences between both groups. miR-181a-5p was significantly overexpressed ( $\mathrm{p}<0.0001$ ) in the ACR group compared with the no-ACR group. Median miR-181a-5p expression levels were 0.465 (IQR:0.338-0.541), and 0.254 (IQR: 0.1550.341 ) in the ACR and no-ACR groups, respectively (Figure 2). Sensitivity analysis(ROC curve) showed that for a miR-181a-5p cut-off of $2^{-\Delta \mathrm{Cq}}>0.33$ ), an AUC of 0.804 (95\% CI: 0.707-0.880) was obtained ( $\mathrm{p}<0.0001$ ) (Figure 2, Supplementary Table S2 online). The sensitivity and the specificity for this cut-off were $78 \%$ and $76 \%$, respectively. For the prevalence obtained of $7 \%$ in this study (EMB $\geq 2 \mathrm{R}$ ), NPV and PPV were $98 \%$ and $20 \%$, respectively. 


\section{Discussion}

MicroRNAs have been postulated as new potential noninvasive biomarker candidates for heart transplant rejection. ${ }^{12-18}$ In this study, after evaluating 179 serum micro-RNAs in the initial discovery phase, the circulating miR-181a-5p showed a rise and fall pattern that make it a potential non-invasive biomarker to detect ACR in HTx. These results were confirmed in the discovery phased using a new cohort of patients with ACR and where miR-181a-5p was found to be overexpressed compared with those with no rejection. Thus, as a non-invasive biomarker for ACR detection in HTx, miR-181a-5p showed promising results, with an AUC of 0.804 (95\% CI: 0.7070.880 ) and a sensitivity and specificity of $78 \%$ and $76 \%$, respectively.

To our knowledge, 12 microRNAs has been previously described ${ }^{12,13,15-17}$ associated with cardiac graft rejection (Table 1). In this study, we tested 10 of these microRNAs (miR-101-3p, miR-142-3p, miR-144-3p, miR-326, miR-339-3p, miR-424-5p, miR-92a, miR-155, miR-29, and miR-27-3p) and none of them presented a rise and fall pattern expression during the rejection event in the cohort studied. The other 2 microRNAs previously described, miR-10a and miR-31, only were associated with ACR in 1 out of the 5 studies previously published. ${ }^{13}$ This lack of reproducibility between the studies could be in part explained by the different designs, the poor standardization, and the use of several normalization methods of the data. In this study, the latest recommendations to standardize the experiments were followed. ${ }^{20}$ First, the longitudinal design of the experiment in the discovery phase, where the same patient is studied before, during, and after the ACR episode, together with an adequate sample size, gave the study a reliable statistical power. Second, in microRNA expression profile experiments, provided the normalization method is correct, there should be as many overexpressed as underexpressed microRNAs. In the discovery phase of this study, after global mean normalization, microRNAs under- and overexpressed were fairly similar, 50\% each (Supplementary Figure S1b online). Finally, in the validation phase, the normalization of RT-qPCR data was performed first, using 2 endogenous reference genes (miR23b-3p and miR-30c-5p) and the geometric mean method.

Sukma Dewi et al. ${ }^{12}$ is the only study where samples before, during, and after cellular rejection were used. Significantly increased levels of miR-326 and miR-142-3p during ACR and an AUC of 0.86 and 0.80 , respectively, were described. ${ }^{12}$ This was a small pilot study with only 10 patients included, and later the same authors increased the cohort $(\mathrm{ACR}=26) .{ }^{17}$ However, the most promising micro-RNA in the previous study, ${ }^{12}$ miR-326, in the new approach presented a lower AUC, 0.69 versus 0.86 . On the other hand, in the study of Duong van Huyen et al., ${ }^{13} 4$ microRNAs (miR-10a, miR-31, miR-92a, and miR-155) differentially expressed in rejection patients with almost perfect ROC curves (AUC $\approx 1$ ) were identified. However, the cohort studied was formed by 14 ACR and 17 AMR patients, and thus the results obtained were not exclusively of cellular rejection after HTx. Thus, although the number of microRNA studies for the detection of ACR is small, all these results suggest that microRNAs could be candidates as biomarkers.

Currently, there is only 1 non-invasive test approved by FDA for monitoring ACR, Allomap (CareDx). ${ }^{6,23,24}$ Allomap, a gene expression profiling test in blood leukocytes, showed an AUC of 0.70, lower than the AUC here obtained for miR-181a-5p (Table 4). Because the estimation of NPVs and PPVs varies based on the disease prevalence of the screened population, an estimated prevalence of $5 \%$ was established to compare results (Table 4). Our results showed that miR-181a5p presented an NPV of 98.5\%, whereas the NPV for Allomap was lower (NPV = 95.7\%). Thus, the results here obtained for miR-181a-5p are similar to or even better than, in terms of AUC and $\mathrm{NPV}$, those of Allomap and other biomarkers under investigation ( $\mathrm{T}$ regulatory cells to endothelial progenitor cells, troponin I, and donor-derived cell-free DNA) (Table 4). ${ }^{7,25,26}$ So, although our results were obtained analyzing 61 EMB blood samples from patients with Grade $\geq 2 \mathrm{R}$ EMB from only 1 hospital and under ideal conditions (no EMB = 1R were included), our data led us to hypothesize that miR-181a-5p may become a useful biomarker for monitoring ACR, using an inexpensive, robust, and feasible technology, which may lead to a reduction in the number of EMBs. 
miR-181a-5p

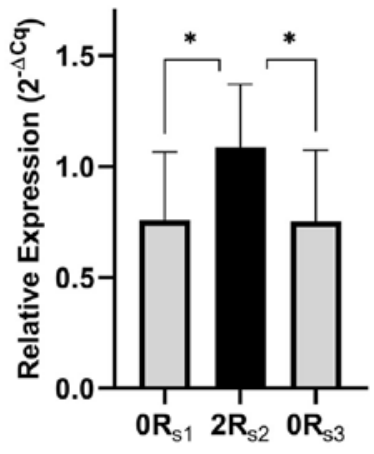

let-7f-5p

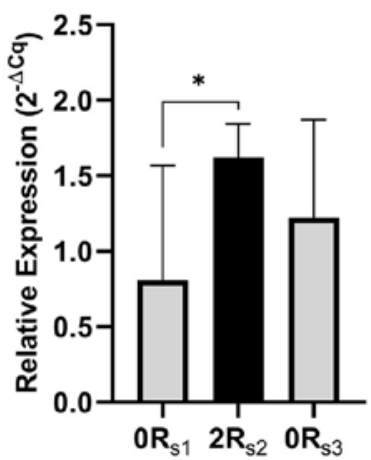

miR-339-3p

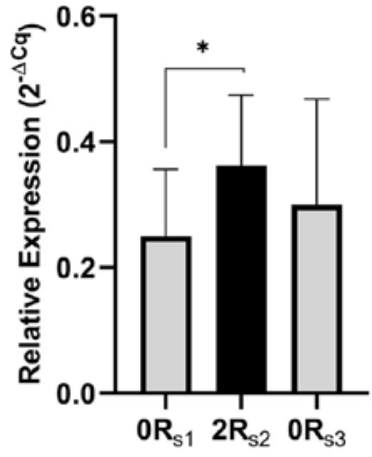

miR-505-3p

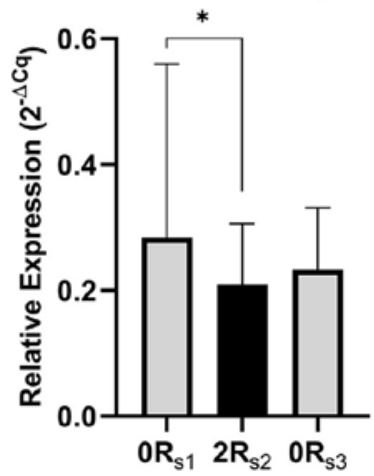

\begin{tabular}{|c|c|c|c|c|c|c|}
\hline & \multicolumn{3}{|c|}{ Relative Expression $2^{-\Delta C q}$} & \multicolumn{3}{|c|}{ Adjusted p-value (ANOVA) } \\
\hline & $\mathbf{O} \mathbf{R}_{\mathbf{S 1}}$ & $2 R_{\mathrm{s} 2}$ & $\mathrm{OR}_{\mathrm{s3}}$ & \begin{tabular}{|c|}
$0 R_{s 1}$ vs \\
$2 R_{s 2}$
\end{tabular} & $\begin{array}{c}2 \mathbf{R}_{\mathrm{s2}} \text { VS } \\
0 \mathbf{R}_{83}\end{array}$ & $\begin{array}{c}\mathbf{O R}_{\mathbf{s 1}} \mathrm{VS} \\
\mathbf{O R}_{53}\end{array}$ \\
\hline miR-181-5p & $\begin{array}{c}0.759 \\
(0.427-1.064)\end{array}$ & $\begin{array}{c}1.085 \\
(0.701-1.371)\end{array}$ & $\begin{array}{c}0.752 \\
(0.597-1.073)\end{array}$ & 0.0194 & 0.0225 & NS \\
\hline miR-339-3p & $\begin{array}{c}0.251 \\
(0.147-0.356)\end{array}$ & $\begin{array}{c}0.362 \\
(0.249-0.474)\end{array}$ & $\begin{array}{c}0.300 \\
(0.209-0.468)\end{array}$ & 0.0442 & NS & NS \\
\hline let-7f-5p & $\begin{array}{c}0.807 \\
(0.683-1.568)\end{array}$ & $\begin{array}{c}1.620 \\
(1.108-1.842)\end{array}$ & $\begin{array}{c}1.224 \\
(0.952-1.871)\end{array}$ & 0.0445 & NS & NS \\
\hline miR-505-3p & $\begin{array}{c}0.284 \\
(0.176-0.560)\end{array}$ & $\begin{array}{c}0.209 \\
(0.125-0.306)\end{array}$ & $\begin{array}{c}0.233 \\
(0.124-0.331)\end{array}$ & 0.0284 & NS & NS \\
\hline
\end{tabular}

Figure 1. Significant differentially expressed microRNAs during ACR episode. Data are presented as median relative expression $\left(2^{-\Delta \mathrm{Cq}}\right)$ (bars) and interquartile range (whiskers). All adjusted p-values were obtained by one-way ANOVA and post-hoc Tukey test. NS if $\mathrm{p} \geq 0.05, \times$ if $\mathrm{p}<0.05$, and $* *$ if $\mathrm{p}<0.005$. ACR, acute cellular rejection; ANOVA, analysis of variance; NS, not significant.

Moreover, it has been described that the miR-181 family regulates $\mathrm{T}$ - and B-cell development, ${ }^{27-30}$ and this function could explain this important role in ACR. Li et al. ${ }^{28}$ demonstrated that miR-181a modulates the sensitivity of $\mathrm{T}$ cells to foreign and endogenous antigens through T-cell receptor signaling. It was also demonstrated that miR-181a overexpression increases the number of B cells. ${ }^{27-29}$ In HTx, during an ACR episode, T cells mediate an inflammatory response that leads to infiltration and lesion of the myocardium by mononuclear cells (activated macrophages, T cells, and B cells). The high grade of evidence that miR-181a is strongly involved in this alloimmune response makes our results very plausible from the biological point of view. This biological evidence supports the idea that miR-181a might be a promising biomarker not only for ACR detection but also for microRNA-based therapies and monitoring the immunosuppressive treatment. 
Table 3. Validation Phase Patients’ Baseline Characteristics

\begin{tabular}{llll}
\hline Patient characteristics & $\begin{array}{l}\text { No-R } \\
\mathrm{n}=45\end{array}$ & $\begin{array}{l}\text { ACR } \\
\mathrm{n}=45\end{array}$ & p-value \\
\hline Males & $36(80 \%)$ & $36(80 \%)$ & - \\
Age at HTx & $60(44-65)$ & $55(49-63)$ & $\mathrm{NS}$. \\
Tacrolimus levels, ng/mL (95\% CI) & $11.1(9.9-12.2)$ & $10.6(9.4-11.7)$ & $\mathrm{NS}$. \\
Serum creatinine, $\mu$ mol/L (IQR) & $110(88-133)$ & $98(77-133)$ & $\mathrm{NS}$. \\
Red blood cells, $\times 10^{12} / \mathrm{L}$ (IQR) & $3.71(3.52-3.89)$ & $3.60(3.48-3.73)$ & $\mathrm{NS}$. \\
Blood platelets, $\times 10^{9} / \mathrm{L}(\mathrm{IQR})$ & $223(199-247)$ & $216(183-249)$ & $\mathrm{NS}$. \\
White blood cells, $\times 10^{9} / \mathrm{L}(\mathrm{IQR})$ & $6.19(5.35-7.92)$ & $6.68(4.58-9.17)$ & $\mathrm{NS}$. \\
Blood lymphocytes, $\times 10^{9} / \mathrm{L}(95 \%$ CI) & $1.14(0.96-1.31)$ & $1.20(1.03-1.37)$ & $\mathrm{NS}$. \\
Blood neutrophils, $\times 10^{9} / \mathrm{L}(\mathrm{IQR})$ & $4.52(3.43-5.93)$ & $4.69(3.06-7.17)$ & $\mathrm{NS}$. \\
\hline
\end{tabular}

ACR, acute cellular rejection; CI, confidence interval; HTx, heart transplantation; IQR, interquartile range; No-R, no rejection; NS, not significant.Limitations

a)

miR-181a-5p
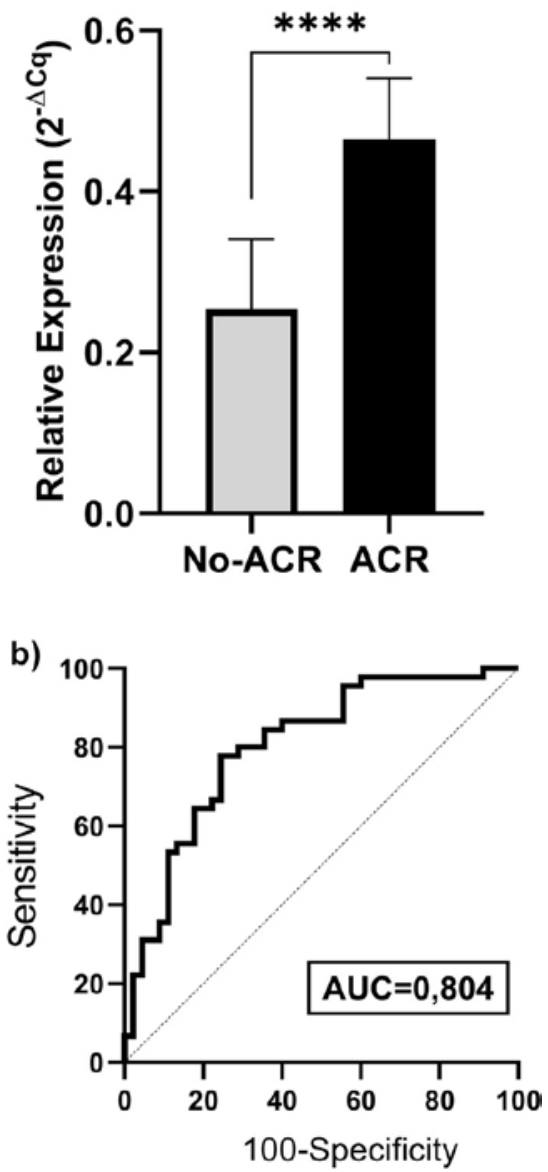

Figure 2. miR-181a-5p expression in validation phase (a) miR-181a-5p relative expression ( $2^{-\Delta C q}$ in no-ACR and ACR groups presented as median (bars) and interquartile range (whiskers); **** if $p<0.0001$. (b) ROC curve for evaluation of serum miR-181a-5p as biomarker to detect ACR. ACR, acute cellular rejection; ROC, receiver operating characteristic 


\section{Limitations}

Our study has several limitations and, although miR-181a-5p seems to be a promising ACR biomarker, it is a long pathway until it can reach its clinical application. First, because of the design of the study, the diagnostic accuracy of miR-181a-5p should be assessed in a larger multicenter prospective cohort with randomly selected patients. It would also be necessary to assess miR-181a-5p in patients with Grade 1R ACR to study if miR-181a-5p correlates with the severity of the rejection episode. Moreover, the effect of different treatments on the levels of miR181a-5p post-rejection should also be analyzed. Finally, although we performed an ambitious study where 179 microRNAs were studied, other microRNAs not included may also have a role in ACR.

Table 4 Characteristics of Biomarkers for ACR Detection Post-HTx

\begin{tabular}{|c|c|c|c|c|c|c|c|c|c|c|}
\hline Biomarker & Ref & Year & Norejection & Acuterejection & $\begin{array}{l}\text { Months } \\
\text { post- } \\
\text { HTx }\end{array}$ & $\begin{array}{l}\text { AUC(95\% } \\
\text { CI) }\end{array}$ & $\mathrm{S}$ & SP & $\mathrm{NPV}^{\mathrm{a}}$ & $\mathrm{PPV}^{\mathrm{a}}$ \\
\hline Allomap & $\begin{array}{l}\text { Crespo- } \\
\text { Leiro et } \\
\text { al. }\end{array}$ & 2016 & 425 & $55 \mathrm{EMB} \geq 2 \mathrm{R}$ & $2-6$ & $\begin{array}{l}0.70 \\
(0.67-0.73)\end{array}$ & 25 & 89 & 95.7 & 10.4 \\
\hline Troponin I & $\begin{array}{l}\text { Patel et } \\
\text { al. }^{26}\end{array}$ & 2014 & 383 & $\begin{array}{l}19 \text { EMB } \geq 2 R \\
8 \text { AMR } \\
5 \text { Mixed } \\
3 \text { HC }\end{array}$ & $>1$ & $\begin{array}{l}0.82 \\
(0.76-0.88)\end{array}$ & 94 & 60 & 99.5 & 11 \\
\hline cfdDNA & $\begin{array}{l}\text { De } \\
\text { Vlaminck } \\
\text { et al. }\end{array}$ & 2014 & 185 & $\begin{array}{l}24 \mathrm{EMB} \geq 2 \mathrm{R} \\
\text { or } \mathrm{AMR}\end{array}$ & $>1$ & 0.83 & 58 & 93 & 97.7 & 30.4 \\
\hline Treg/EPC & $\begin{array}{l}\text { Choi et } \\
\text { al. }^{25}\end{array}$ & 2018 & 91 & $\begin{array}{l}19 \mathrm{EMB} \geq 2 \mathrm{R} \\
8 \mathrm{HC}\end{array}$ & - & $\begin{array}{l}0.71 \\
(0.59-0.84)\end{array}$ & - & - & - & - \\
\hline miR-181a-5p & $\begin{array}{l}\text { This } \\
\text { study }\end{array}$ & - & 45 & $45 \mathrm{EMB} \geq 2 \mathrm{R}$ & $1-6$ & $\begin{array}{l}0.80 \\
(0.71-0.88)\end{array}$ & 78 & 76 & 98.5 & 14.6 \\
\hline
\end{tabular}

ACR, acute cellular rejection; AMR, antibody-mediated rejection; AUC, area under the curve; cfdDNA, cell-free donorderived DNA; EMB, endomyocardial biopsy; HC, hemodynamic compromise; HTx, heart transplantation; NPV, negative predicted value; PPV, positive predicted value; S, sensitivity; SP, specificity; Treg/EPC, T regulatory cells to endothelial progenitor cells.

${ }^{a}$ NPV and PPV calculated for an arbitrary prevalence of 5\% for acute rejection.

\section{Conclusions}

miR-185a-5p in serum is a candidate as a non-invasive ACR biomarker with an AUC of 0.80 and an NPV of 98\%. Thus, this biomarker could reduce the need for EMBs and the associated risks and costs of this invasive procedure.

\section{Disclosure statement}

The authors have no conflicts of interest to disclose.

This study received financial support from Instituto de Salud Carlos III (PI15/02224), is part of the research activities of the Centro de investigación Biomédica en Red Enfermedades Cardiovasculares (CIBERCV), and was cofinanced with FEDER Funds. 


\section{Supplementary materials}

Supplementary material associated with this article can be found in the online version at https://doi.org/10.1016/j.healun.2020.05.018.

\section{References}

1. Khush KK, Cherikh WS, Chambers DC, et al. The International Thoracic Organ Transplant Registry of the International Society for Heart and Lung Transplantation: thirty-sixth adult heart transplantation report - 2019; focus theme: donor and recipient size match. J Heart Lung Transplant 2019;38:1056-66.

2. Hamour IM, Burke MM, Bell AD, Panicker MG, Banerjee R, Banner NR. Limited utility of endomyocardial biopsy in the first year after heart transplantation. Transplantation 2008;85:969-74.

3. Crespo-Leiro MG, Zuckermann A, Bara C, et al. Concordance among pathologists in the second Cardiac Allograft Rejection Gene Expression Observational Study (CARGO II). Transplantation 2012;94:1172-7.

4. Miller CA, Fildes JE, Ray SG, et al. Non-invasive approaches for the diagnosis of acute cardiac allograft rejection. Heart 2013;99:445-53.

5. Kobashigawa J, Patel J, Azarbal B, et al. Randomized pilot trial of gene expression profiling versus heart biopsy in the first year after heart transplant: early invasive monitoring attenuation through gene expression trial. Circ Heart Fail 2015;8:557-64.

6. Crespo-Leiro MG, Stypmann J, Schulz U, et al. Clinical usefulness of gene-expression profile to rule out acute rejection after heart transplantation: CARGO II. Eur Heart J 2016;37:2591601.

7. De Vlaminck I, Valantine HA, Snyder TM, et al. Circulating cell-free DNA enables noninvasive diagnosis of heart transplant rejection. Sci Transl Med 2014;6:241ra77.

8. Wang J, Chen J, Sen S. MicroRNA as biomarkers and diagnostics. J Cell Physiol 2016;231:25-30.

9. Shah P, Bristow MR, Port JD. MicroRNAs in heart failure, cardiac transplantation, and myocardial recovery: biomarkers with therapeutic potential. Curr Heart Fail Rep 2017;14:454-64.

10. Pritchard CC, Cheng HH, Tewari M. MicroRNA profiling: approaches and considerations. Nat Rev Genet 2012;13:358-69.

11. Chen X, Ba Y, Ma L, et al. Characterization of microRNAs in serum: a novel class of biomarkers for diagnosis of cancer and other diseases. Cell Res 2008;18:997-1006.

12. Sukma Dewi I, Torngren K, Gidl€of O, Kornhall B, Ohman J. Altered serum miRNA profiles during acute rejection after heart transplantation: potential for non-invasive allograft surveillance. J Heart Lung Transplant 2013;32:463-6.

13. Duong Van Huyen JP, Tible M, Gay A, et al. MicroRNAs as non-invasive biomarkers of heart transplant rejection. Eur Heart J 2014; 35:3194-202.

14. Van Aelst LNL, Summer G, Li S, et al. RNA profiling in human and murine transplanted hearts: identification and validation of therapeutic targets for acute cardiac and renal allograft rejection. Am J Transplant 2016;16:99-110.

15. Guo S, Guo X, Wang S, Nie Q, Ni G, Wang C. Role of miR-29 as marker of risk of acute rejection after heart transplant. Br J Biomed Sci 2017;74:187-92.

16. Sukma Dewi I, Celik S, Karlsson A, et al. Exosomal miR-142-3p is increased during cardiac allograft rejection and augments vascular permeability through down-regulation of endothelial RAB11FIP2 expression. Cardiovasc Res 2017;113:440-52.

17. Sukma Dewi I, Hollander Z, Lam KK, et al. Association of serum miR-142-3p and miR-101$3 p$ levels with acute cellular rejection after heart transplantation. PLoS One 2017;12:e0170842.

18. Di Francesco A, Fedrigo M, Santovito D, et al. MicroRNA signatures in cardiac biopsies and detection of allograft rejection. J Heart Lung Transplant 2018;37:1329-40.

19. Leidner RS, Li L, Thompson CL. Dampening enthusiasm for circulating microRNA in breast cancer. PLoS One 2013;8:e57841. 
20. de Ronde MWJ, Ruijter JM, Moerland PD, Creemers EE, Pinto-Sietsma SJ. Study design and qPCR data analysis guidelines for reliable circulating miRNA biomarker experiments: a review. Clin Chem 2018;64:1308-18.

21. Kitchen RR, Kubista M, Tichopad A. Statistical aspects of quantitative real-time PCR experiment design. Methods 2010;50:231-6.

22. Stewart S, Winters GL, Fishbein MC, et al. Revision of the 1990 working formulation for the standardization of nomenclature in the diagnosis of heart rejection. J Heart Lung Transplant 2005;24:1710-20.

23. Deng MC, Eisen HJ, Mehra MR, et al. Noninvasive discrimination of rejection in cardiac allograft recipients using gene expression profiling. Am J Transplant 2006;6:150-60.

24. Pham MX, Teuteberg JJ, Kfoury AG, et al. Gene-expression profiling for rejection surveillance after cardiac transplantation. N Engl J Med 2010;362:1890-900.

25. Choi DH, Chmura SA, Ramachandran V, et al. The ratio of circulating regulatory cluster of differentiation $4 \mathrm{~T}$ cells to endothelial progenitor cells predicts clinically significant acute rejection after heart transplantation. J Heart Lung Transplant 2018;37:496-502.

26. Patel PC, Hill DA, Ayers CR, et al. High-sensitivity cardiac troponin I assay to screen for acute rejection in patients with heart transplant. Circ Heart Fail 2014;7:463-9.

27. Chen CZ, Li L, Lodish HF, Bartel DP. MicroRNAs modulate hematopoietic lineage differentiation. Science 2004;303:83-6.

28. Li QJ, Chau J, Ebert PJR, et al. miR-181a is an intrinsic modulator of T cell sensitivity and selection. Cell 2007;129:147-61.

29. Lwin T, Lin J, Choi YS, et al. Follicular dendritic cell-dependent drug resistance of nonHodgkin lymphoma involves cell adhesion-mediated Bim down-regulation through induction of microRNA-181a. Blood 2010;116:5228-36.

30. Vitalone MJ, Sigdel TK, Salomonis N, Sarwal RD, Hsieh SC, Sarwal MM. Transcriptional perturbations in graft rejection. Transplantation 2015;99:1882-93. 